\title{
Issues and Challenges of Halal Implementation in Food Industry in Malaysia
}

\author{
[ Asnidar Hanim Yusuf, Syadiyah Abdul Shukor, Ummi Salwa Ahmad Bustamam ]
}

\begin{abstract}
This paper aims to provide explanations on issues and challenges faced by Malaysian food industry in Halal implementations. Halal food is no longer considered solely as a religious requirement for the Muslims, but also sought by non-Muslim community because of cleanliness, safety and hygiene issue. Food business practitioners faced various kinds of issues and challenges in order to implement the Halal concept in their daily operations. This conceptual paper will outline the issues and challenges from various perspectives; authority, awareness, consumer perception, cost, market competitiveness, and supply chain management to help business practitioners and others in the food industry to understand the current issues. Further studies are suggested to analyze the problems and figure out the solution for the current problems.
\end{abstract}

Keywords-Halal concept, Halal implementation, Islamic dietary, issues and challenges

\section{Introduction}

Malaysia's Halal food production contributes significantly to the nation's economic development as well as the global economy [12]. The size of Halal food market is USD 8.6 billion in 2010 according to [2] as quoted from Chan (2011). Due to Malaysian government various supports to help establish Halal Hub in this country, Halal certificate industries have increased by $20 \%$ from Year 2009 to Year 2010. 65\% of the Halal certified companies derived from food cluster industries [10]. By the year 2012, there were already 2629 food premises which were granted with the Halal certification, according to [3] as cited from Halal Development Council (HDC) (2012).

\section{Asnidar Hanim Yusuf}

Universiti Sains Islam Malaysia

Malaysia

Dr. Syadiyah Abdul Shukor

Universiti Sains Islam Malaysia

Malaysia

Dr. Ummi Salwa Ahmad Bustamam

Universiti Sains Islam Malaysia

Malaysia
In Malaysia, where the population of Muslim reached about $60 \%$ of the whole country, the demand for Halal products is more than RM5 billion a year [15].

\section{A. Definition of Halal}

Muslims are required to follow the requirement of Islamic law that teaches to consume only Halal food and avoid the Haram ones. Apart from food, Muslims must also abide the rules of conducting Halal concept in their daily lives.

The word Halal is originated from Arabic word which means lawful and permissible according to Islamic Syariah law which refers to the teachings of Al-Quran and exemplary conduct of Prophet Muhammad (peace and blessings of Allah be upon Him) as quoted in the Hadith. The opposite of Halal is Haram which means forbidden [18] as quoted from Roland (1996).

\section{B. Government support in Halal Industry}

In order to make Malaysia as a Halal hub, the government has taken measures to support the growth of Halal industry in this country [6].

Third Industrial Master Plan (IMP3) has been launched to provide opportunities in Halal industry development. As for Halal food production, special tax incentives have been introduced. Halal certified companies are eligible for Investment Tax Allowance of $100 \%$ of qualifying capital expenditure in five years according to [1] as quoted from Amanda (2012).

\section{Issues and Challenges in Halal Implementation}

There are various issues and challenges available in the current literature reviews. Among the widely discussed areas are authority, awareness, consumer perceptions, cost, market competitiveness, and supply chain management.

\section{A. Authority}

Reference [16] highlighted several problems in the process of Halal Certificate applications which are caused by both applicants (business owners) and the authority such as 
Proc. of the Third Intl. Conf. on Advances in Economics, Management and Social Study - EMS 2015

Copyright (C) Institute of Research Engineers and Doctors, USA .All rights reserved.

ISBN: 978-1-63248-058-3 doi: 10.15224/ 978-1-63248-058-3-53

Department of Islamic Development Malaysia (JAKIM) and Halal Development Corporation (HDC). From the applicants' side, the lack of understanding of the Halal procedure is one of the problems that usually arise. However, this is sometimes due to ignorance from the business owners' part even though information on the Halal procedure is widely available. If the business owners are already committed to applying the Halal certification, they sometimes delay their submission of the supporting documents needed for the application. Sometimes, the documents submitted are not complete, causing delay for the whole process. Even when the business owners have gone through the whole application process, there are cases where the business owners delay their payment for the certification fee. And finally, sometimes the business owners claimed that they are not aware of the notification via email or e-Halal information system that has been sent to them upon any stages of the Halal certification application.

Whereas on JAKIM's side, there are also several problems that usually occur in the Halal certification application process. First of all, there is lack of expertise in the Halal certification area. This caused slow processing due to inexperienced staff. Other matters such as clerical problems like improper filing will also contribute to the inefficiency of the operation. In order to certify larger organizations like multinational manufacturing companies or hotel chains, premise inspection may take longer time and require the certification officers to be out of their desk work for longer periods. Another problem that arises is the delay in receiving lab test result. Summary of the problems are shown in Table 1.

TABLE I. OPERATIONAL INEFFICIENCY IN HALAL CERTIFICATION

\begin{tabular}{|l|l|}
\hline \multicolumn{1}{|c|}{ Applicants } & \multicolumn{1}{|c|}{ Internal } \\
\hline $\begin{array}{l}\text { Lack of understanding of the Halal } \\
\text { procedure }\end{array}$ & $\begin{array}{l}\text { Lack of expertise as new staff with } \\
\text { little experience of the system } \\
\text { contribute to the slow processing } \\
\text { and without a tight coordination } \\
\text { will minimize the number of Halal } \\
\text { certificate approval }\end{array}$ \\
\hline $\begin{array}{l}\text { Delay in submitting the supporting } \\
\text { documents }\end{array}$ & $\begin{array}{l}\text { Unsystematic filing system also } \\
\text { contribute to the inefficient } \\
\text { operational }\end{array}$ \\
\hline $\begin{array}{l}\text { Delay in making payments of } \\
\text { certificate fee }\end{array}$ & $\begin{array}{l}\text { Premise inspection may require } \\
\text { more than a day to be completed } \\
\text { especially for the multinational } \\
\text { industry and hotels. }\end{array}$ \\
\hline $\begin{array}{l}\text { Unaware of the acknowledgement that } \\
\text { has been sent to them through the } \\
\text { email or e-Halal information system }\end{array}$ & Delay in receiving lab test result \\
\hline
\end{tabular}

In a study conducted by [22] it is understood that there are no law or regulations in Malaysia that require any business entities to get Halal certified, but once the business Halal certificate is approved, the companies are subjected to the law which means that any violation of the Section 3 of Trade Description Order 1975 (Use of Halal Expression) will be imposed as criminal act. Consequently, if the companies are not certified Halal, they are not subjected to this section. Similarly, [7] also cited from Riaz and Chaudry (2004) on the Trade Description Order 1975 on the offense to falsely label food as Halal and Trade Description Act of 1975 on the offense to falsely claim the food to be Halal on signs and other markings.

Based on the reasons that have been widely discussed in present literature as stated above, many business owners choose not to go for Halal Certification and choose to operate without the certificate in Malaysia.

\section{B. Awareness}

Reference [21] reported that despite Malaysia's Tourism Ministry's effort to make Malaysia as tourism hub among the Islamic countries, there are still low rate of Halal certification application among hotels in this country. The study found that lack of awareness on the importance of Halal implementation among the hoteliers that leads to this. At the same time, Muslim tourists particularly from West Asia are concerned about the Halal status of the food and accommodation in the countries that they visit thus the requirement for Halal compliance among the hotels in Malaysia is more prevalent. Halal tourism has also become a new phenomenon in tourism across the globe due to safety, hygiene and quality assurance provided by the Halal certified hotels.

Similarly, [17] also mentioned that many non Muslim consumers in Malaysia have started to purchase and consume Halal food because it is a healthy choice and the rise of health conscious community in the country.

\section{Cost}

Another challenge faced by food business operators in Malaysia who are interested in implementing Halal concept and apply for certification is the cost incurred in order to ensure the overall implementation. The increase of manufacturing and operating cost has also become one of the reasons why there are still not many companies who come forward to apply for the Halal certification.

The increase is said to be up to ten percent than the usual standard manufacturing cost to set up Halal Certified business. The burden of the extra cost is very heavy especially for first timer of certain businesses. The extra costs are needed because as a Halal certified company, they need to use segregated equipments and transportation to differentiate between Halal and non Halal products. Suppliers who provide Halal goods also charge the business owner more. In order to get the certification, the compliance cost must also be considered to be paid for consultancy job and certification process [9]. 
Proc. of the Third Intl. Conf. on Advances in Economics, Management and Social Study - EMS 2015

Copyright (C) Institute of Research Engineers and Doctors, USA .All rights reserved.

ISBN: 978-1-63248-058-3 doi: 10.15224/ 978-1-63248-058-3-53

In a study conducted by [4], among the factors of non compliance of Halal certification which was studied in restaurants around Kuala Lumpur was because of the cost of implementations and cost of changes due to rectification that needs to be done after the audit from Jakim officers. The same problem was highlighted in a case study conducted by [14] that said the implementation of Halal certification will produce higher cost to the business organizations due to food sampling and laboratory test required to check on the material ingredients.

Naturally, business owners with limited financial resources will think twice to pursue with Halal certification if there are extra cost incurred in the process of applying the certification.

\section{Consumer Perception}

Recently, the Halal market not only attracts Muslim population but also non Muslim consumers. However the perception towards Halal product and purchase intention is not quite the same as Muslim consumers usually consider Halal food product mainly because of religious issue, while the increasing demand from non Muslim consumers in Malaysia is influenced by the growing concern of health-conscious community that request for well prepared product in terms of slaughtering process, cleanliness and other reasons.

Furthermore, culture assimilation in a multiracial country like Malaysia has shaped the purchase intention of non Muslim consumers towards Halal food products [8].

\section{E. Market Competitiveness}

In Malaysia, there are a lot of small medium enterprises (SMEs) that are involved in Halal food product. However, because they are small, the market competitiveness among their business rivals are very challenging due to capital constraints, competition, technology, weak business networks and lack of experience in marketing their products according to [6] as cited from Sazelin Arif (2008). These barriers caused the SME products to be in poor quality compared to multinational companies' products.

Another factor that determines market competitiveness that should be looked upon is branding. It can contribute to the competitiveness of the country's goods and services. Due to the liberalization in the international trading environment, developments in ICT and rapid changes caused by globalization, consumers have wide choice of products to choose [13]. However, [11] also indicated that SMEs in Malaysia do not consider branding as one of the core strategy to compete globally. In order to penetrate new market opportunities, SMEs should strengthen the branding position, revolutionize, adopt and adapt to compete and remain relevant to the current market.

Decision makers of SMEs involved in Halal food form their competitive map based on characteristic of the firm's environment, business definition, and strategy. The study conducted by [2] proved that the SMEs management agreed that Halal certification promotes satisfaction, confidence and trust that eventually lead to the increase of market share and market competitiveness.

However, information on Halal hub are insufficient, not updated and not published in regularly accessed media causing difficulty for the SMEs business owners to participate in Halal implementation activities.

[The lack of understanding of the Halal procedure is one of the problems that usually arise. However, this is sometimes due to ignorance from the business owners' part even though information on the Halal procedure is widely available.]

\section{F. Supply Chain Management}

Supply chain management (SCM) in Halal food industry basically means managing the Halal food products from different level of suppliers to different level of buyers or consumers [20]. Reference [5] explained how supply chain in Halal food industry worked in Malaysia based on Figure 1 below. The flow chart shows how Halal SCM applies from farm to different types of suppliers and users until the products reach the consumers.

Among the problems faced by Halal SCM according to [12] are lack of clear standardization in between local livestock or fish growers and other marketing intermediaries, inefficiency among the supplier tiers such as the issues of halal status, quality, quantity and costing. In terms of logistic, the problems arise in transportation, warehousing and storing (possibilities of mixed storages and cross contamination).

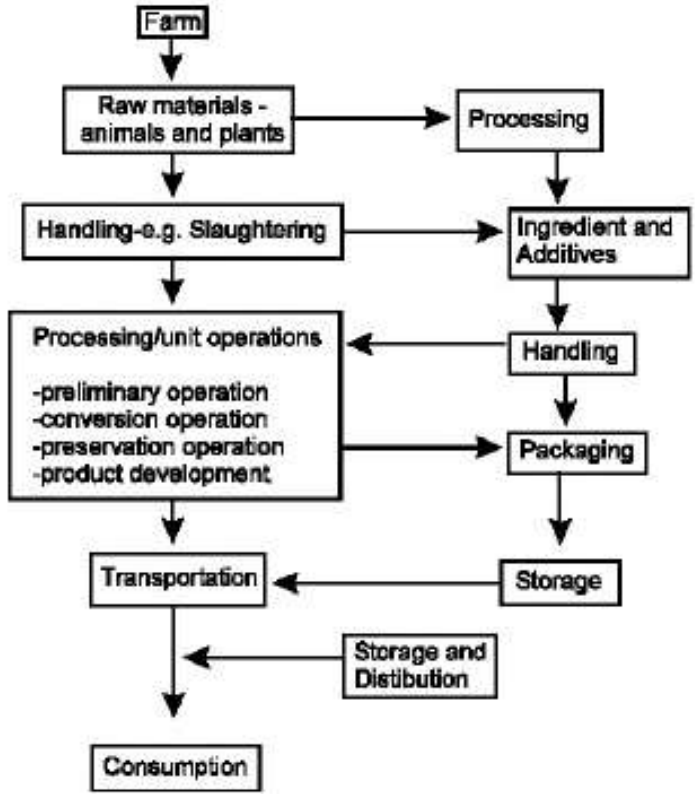

Figure 1. Halal supply chain management. 
As mentioned by [19], in ensuring the integrity of Halal products, logistic service management capabilities play an important role. The paper suggested the usage of tracking system to avoid cross contamination during logistic of the Halal products starting from collection, consolidation, storage handling, value added, track \& trace, controls the movement, and storage of products as cited from (Tan and Ibrahim, 2010).

Similarly according to [20] Halal integrity in SCM is doubted because Halal food travels a great distance before reaching the end user thus allowing the possibilities of cross contamination along the way.

\section{Conclusion}

Halal food products are one of the main components of the Halal industry in Malaysia. It is growing more and more every year and contributes largely to Malaysian economic growth. However, there are issues and challenges faced by the food industry operators in order to implement Halal concept in their businesses.

This paper discussed the issues and challenges in various points of views to get a clearer picture of the current situation. Among problems that are identified in this study involved authority, awareness, consumer perception, cost, market competitiveness, and supply chain management that had been discussed in the current literature reviews.

By outlining these problems, it is hoped that future research will be conducted to discuss suggestions and identify solutions for the problems that have been raised in this paper so that food business operators in Malaysia have solid platform to implement the Halal concept in their businesses.

\section{References}

[1] A. Abdul Raufu and B. Ahmad Naqiyuddin, “ People's Awareness on Halal Foods and Products: Potential Issues for Policy- Makers, “ International Halal Conference, Procedia- Social and Behavioral Sciences 121, pp. 3-25, 2014.

[2] A. Mohani, I. Hashanah, and M. Mazlina, " Halal Food Certification: Case of Malaysian SME Enterpreneurs, " China-USA Business Review, ISSN 1537-1514, vol. 12, no. 2, pp. 163-173, February 2013.

[3] A. Nor Ardyanti, T.A. Tunku Nashril, and A.Y.Mohd Helmi, “ A Study on Halal Food Awareness Among Muslim Customers in Klang Valley, “ $4^{\text {th }}$ International Conference on Business and EconomicResearch Proceeding, ISBN: 978-967-5705-10-6, 2013.

[4] A.R. Ilya Nur, S. Rosli, A.R. Suhaimi, and M.H. Dzulkifli, " Factors Contributing to non-Compliance of the Halal Standard among Restaurant Operators in Malaysia, $2^{\text {nd }}$ International Conference on Business, Economics and Tourism Management, IPEDR vol. 24, 2011.

[5] C.M. Yaakob, J. Bojei,A.Q. Sazili, and A.N. Abdullah, "Halal Hub Opportunities, "4th Asian Livestock and Feed Industry Conference Proceeding, 2007.

[6] C.O. Che Mohd Zulkifli and T. Anas, "Challenges and Marketing Strategies of Halal Products in Malaysia, " $5^{\text {th }}$ International Conference on Business and Economic Research Proceeding, March 2014.

[7] F. Johan, " The Halal Frontier, Muslim Consumers in a Globalized Market, " Palgrave Macmillan, New York, 2011.
[8] I. Farah Raihana and N. Kauthar, " Perception of Non-Muslim Consumers towards Halal Products in Malaysia, " International Journalof Accounting and Business Management, vol. 2, issue 1, pp. 128-133, April 2014.

[9] L. Ren Jan, "Marketing Halal, Creating New Economy, New Wealth, “ MPH Publishing, Petaling Jaya, 2012.

[10] M. Alfi Khairiansyah, A.D. Abdul Rahman, K. Jawdat, and A. Ahmed Abdulazez, "Collaboration, Wealth and Value Creation, SME's Halal Products Communities and Information Systems, " International Journal on New Computer Architecture and TheirApplications (IJNCAA)1(2). The Society of Digital Information and Wireless Communications(ISSN:2220-9085), pp. 510-518, 2011.

[11] M. Mohd Zulkifli, C. Abdul Kamal, Y. Mohd Rushdan, and H. Zakiah, "Small and Medium Enterprises (SMEs) Competing in the Global Business Environment: A Case of Malaysia,'International Business Research, vol. 3, no. 1, pp. 66-75, 2010.

[12] M. Z. Suhaiza Hanim, A. Zainal Ariffin, A. W. Nabsiah, O. Rosly, and F. Yudi, " Recommendations to Strengthen Halal Food Supply Chain for Food Industry in Malaysia, Journalof Agribusiness Marketing. Special Edition, pp. 91-105, 2010.

[13] M.D. Nuradli Ridzwan Shah, N. Mohammad Noorizzuddin, N. Norhaziah, and M. Hartini, "Is Halal Products are More Expensive as Perceived by the Consumers? Muslimpreneurs Challenges and Opportunities in Establishing a Blue Ocean Playing Field, "Journal of Management \& Muamalah KUIS, pp. 39-62, 2009.

[14] M.S. Sariwati and A.L. Nurul Akma, "Halal Certification on Chocolate Products, " International Halal Conference, Procedia - Social and Behavioral Sciences 121, pp. 104-112, September 2012.

[15] N. Azah Anir, M.N. Mohd Hairul Nizam,and A. Masliyana, "bThe Users Perceptions and Opportunities in Malaysia in Introducing RFID System for Halal Food Tracking, WSEAS Transactions on Information Science and Applications, vol 5, issue 5, May 2008.

[16] N. Nurulhuda, M.N. Nor Laila, H. Mardziah, and S. Zainal, "Value Chain of Halal Certification System: A Case of the Malaysia Halal Industry, " European and Mediterranean Conference on Information System, July 2009.

[17] P. Kit Teng, W.J. Wan Jamaliah, H. Koon Siong, and M. Mohammad Mahdi, “ Awareness, Recognition and Intention: Insights from a NonMuslim Consumer Survey Regarding Halal labelled Food Products in Malaysia, " $3^{\text {rd }}$ International Conference on Management Proceeding, June 2013.

[18] R. Husain, I. Abd Ghani, A.F. Mohammad, and S. Mehad, "Current Practises Among Halal Cosmetics Manufacturers in Malaysia, "Journalof Statistical Modelling and Analytic, vol. 13, no. 1, ISSN 2180-3102, 2012.

[19] T. Mohd Iskandar Ilyas, R. Raziah Noor, and H. Zuhra Junaida, “ The Adoption of Halal Transportations Technologies for Halal Logistics Service Providers in Malaysia, "World Academy of Science, Engineering and Technology, International Journal of Mechanical, Aerospace, Industrial and Mechatronics Engineering, vol. 6, no. 3, pp. 16-23, 2012.

[20] Z. Mohd Hafiz, M. A. Marhani, A. T. Mohamed Syazwan, “ Conceptual Framework on Halal Food Supply Chain Integrity Enhancement, “ International Halal Conference, Procedia - Social and Behavioral Sciences 121, pp. 58-67, September 2012.

[21] Z. Suhaiza, O. Azizah, and K. Simon, "An exploratory Study on the Factors Influencing the Non-Compliance to Halal Among Hoteliers in Malaysia, “ International Business Management 5(1), pp. 1-12, ISSN:1993-5250, Medwell Journals, 2011.

[22] Z. Zalina, “ Tapping Into the World Halal Market: Some Discussions on Malaysian Laws and Standards, "Shariah Journal, vol 16, Special Edition, pp. 603-616, 2008. 


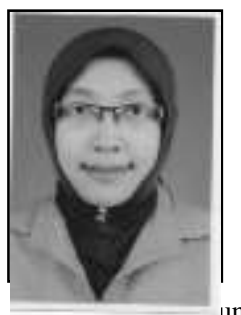

Asnidar Hanim Yusuf is a $\mathrm{PhD}$ student in the Faculty of Economics and Muamalat, Universiti Sains Islam Malaysia.

She was born in Kangar,Perlis in Malaysia on $2^{\text {nd }}$ September 1977. She obtained her Master degree in Industrial and Technology Management from Universiti Kebangsaan Malaysia in 2011.

Before pursuing her $\mathrm{PhD}$ she was working as an engineer in various multinational companies. to Kuala Lumpur.

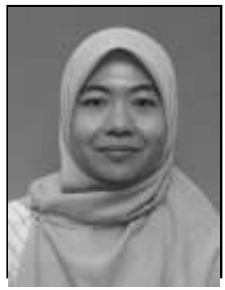

Syadiyah Abdul Shukor is a Senior Lecturer and Head Programme of Marketing (Financial Services) Programme at the Faculty of Economics and Muamalat, Universiti Sains Islam Malaysia.

She obtained her PhD in Marketing from Cardiff Business School. Her research interests include social influence, consumer consumption and marketing of Islamic financial services. She has published more than 20 articles including journal papers, proceedings (locally and internationally) and chapters in book.

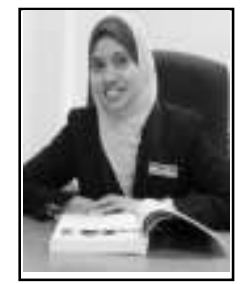

Ummi Salwa Ahmad Bustamam is a Senior Lecturer at the Faculty of Economics and Muamalat, Universiti Sains Islam Malaysia (USIM) and currently the Director of Centre of Student Entrepreneurship Development at USIM.

She obtained her $\mathrm{PhD}$ in Strategic Management from La Trobe University, Australia. Her research interests include small and medium enterprises, entrepreneurship and growth strategies. She has published more than 20 articles including journal papers, case studies, and proceedings (locally and internationally) and chapters in book. 